IRSH 65 (2020), pp. 467-479 doi:10.1017/S0020859020000565

(C) 2020 Internationaal Instituut voor Sociale Geschiedenis. This is an Open Access article, distributed under the terms of the Creative Commons Attribution licence (http://creativecommons.org/licenses/by/4.o/), which permits unrestricted re-use, distribution, and reproduction in any medium, provided the original work is properly cited.

\title{
Nature, Labour, and the Making of Ecological Peripheries
}

\author{
COREY ROSS \\ Department of History, University of Birmingham \\ Birmingham BIs 2 TT, United Kingdom \\ E-mail: c.d.ross@bham.ac.uk
}

\begin{abstract}
This article briefly considers how the integration of the biophysical world into our analyses of the past can enhance our understanding of the socio-economic inequalities of the modern world. Taking Ulbe Bosma's The Making of Periphery as its central reference point, it argues that the process of "peripheralization" - generally treated as an economic or social phenomenon - can also be usefully approached as an interaction between human and non-human forces. It uses the example of Southeast Asian rubber production to show how the different arrangements of people, plants, soil and water on European estates and indigenous smallholdings gave the latter distinct ecological advantages that boosted their oft-cited economic competitiveness, and that consequently forced plantations to extract even more value from cheap labour. In this sense, the environmental history of Southeast Asian rubber offers further evidence for Bosma's core theses about the heterogeneity of peripheralization processes and the importance of demography and labour relations in shaping them.
\end{abstract}

Writing good history is about striking balances - between different scales of analysis, between diverse interpretive viewpoints, between attention to detail and the need to generalize. There is obviously no ideal formula for weighing up these conflicting imperatives. Different selections of content and different points of emphasis have their own advantages and disadvantages, and the choices historians make allow them to address different questions and speak to various debates. The impossibility of establishing any universal standard means that one can never say that a particular historical account ever got these choices entirely "right". Nevertheless, one of the hallmarks of an excellent work of history is that its basic decisions about overall size and shape, its 
choices about scale and focus, appear to maximize the analytical rewards while minimizing the drawbacks. It is noticeable, in other words, when a book seems to get much more right than wrong.

Ulbe Bosma's The Making of a Periphery is an admirable example. It is broadly conceived, yet attentive to detail. It makes a bold intervention on a big and important subject, yet it does so in a way that is highly sensitive to local complexities. Its central thesis goes to the heart of recent debates about the origins of the economic inequalities that shape the modern world. Taking island Southeast Asia as its object of analysis, it argues that the relegation of the region to the peripheries of the global economy cannot be adequately explained as a comprehensive process of "deindustrialization" that converted it into a supplier of labour and raw materials. Rather, this transformation was also crucially dependent on local demographic circumstances and mechanisms of labour mobilization and control, above all the evolution of existing patron-client relations.

It is an ambitious thesis that qualifies one of the dominant interpretations of global comparative development in the modern era, namely the idea that particular economic institutions - and especially the security of private property explain the growing divergences of wealth between different countries and world regions over the past couple of centuries. ${ }^{\text {I }}$ Marshalling a wealth of empirical evidence, Bosma shows that the matter was not so simple. One of the things that makes his intervention so persuasive is its attention to the intricacies of region, gender, and ethnicity, which are usually absent from more macro-level accounts. The global "peripheries" of Asia, Africa, and the Americas may have shared certain fates and experiences, but the various outcomes and the processes that brought them there were far from homogenous. ${ }^{2}$ As Bosma's work demonstrates, even within island Southeast Asia the changes were driven by different sets of factors in different areas; conditions in the Asian colonial "heartlands" of Luzon and Java were quite unlike those in the "outer isles".

To date, arguments about the origins of global inequalities have largely been the preserve of economic historians. The Making of a Periphery shows how social historians can significantly enrich the debate. But this raises the question of whether there might be other analytical possibilities, other perspectives that

I. Most notably, Daron Acemoğlu, Simon Johnson, James A. Robinson, Why Nations Fail: The Origins of Power, Prosperity, and Poverty (New York, 2012).

2. See e.g. Kenneth Pomeranz, The Great Divergence: China, Europe, and the Making of the Modern World Economy (Princeton, NJ, 2000); Jürgen Osterhammel, Die Verwandlung der Welt. Eine Geschichte des 19. Jabrbunderts (Munich, 2009); Eric Jones, The European Miracle: Environments, Economies and Geopolitics in the History of Europe and Asia, (Cambridge, 2003); Prasannan Parthasarathi, Why Europe Grew Rich and Asia Did Not: Global Economic Divergence, I600-I850 (Cambridge, 20I I). 
might fruitfully be brought to bear on the history of global divergences. To what extent can we view "peripheralization" not just as an economic or social process, but as a biophysical and ecological one as well? At a basic level, of course, the transition of large parts of the world to the margins of the global economy inevitably had an ecological dimension. Like any other human activity, it involved various changes to how land and resources were used, and how people accessed and related to them. But the question of biophysical "effects" hardly exhausts the ways in which an environmental history perspective can add to the debate. A far more promising way of understanding its potential is to approach the making of a periphery as an interaction between human and non-human forces, as a socio-ecological project in and of itself. ${ }^{3}$

After all, imperialism and the expansion of capitalism sought not only to modify and subjugate the social world, but also fundamentally to reorder nature-society arrangements across large parts of the globe. As scholars such as Jason Moore and John Bellamy Foster have shown, we can gain new insights into the creation of global peripheries by rooting world systems analysis more firmly in the stuff of life. ${ }^{4}$ When viewed from a biophysical perspective, capitalism appears as a way of organizing not just human production, but also nature itself. According to Moore, the nexus of capitalism, nature, and imperial expansion is bound together by a set of "cheap" things: cheap labour; food; energy; and raw materials. ${ }^{5}$ Only by appropriating these four elements was it possible to maintain the "ecological surplus" that was channelled into capitalist growth and the rising wealth of the world's metropoles. From this point of view, capital accumulation relied not only on large amounts of unpaid or undervalued work - the focus of most historical analysis so far - but also on the exploitation of enormous quantities of uncommodified energy, food, and raw materials provided by nature itself. ${ }^{6}$

The natural world thus subsidized the expansion of capitalism through these "free" inputs. At the same time, it also provided the ultimate sink for

3. Alf Hornborg, "Introduction: Environmental History as Political Ecology", in Alf Hornborg, John R. McNeill, and Joan Martinez-Alier (eds), Rethinking Environmental History: World-System History and Global Environmental Change (Lanham, MD, 2007), pp. I-24; Jason W. Moore, “'Amsterdam is Standing on Norway' Part II: The Global North Atlantic in the Ecological Revolution of the Long Seventeenth Century”, Journal of Agrarian Change, 10 (2010), pp. I 88-227.

4. Jason W. Moore, Capitalism in the Web of Life: Ecology and the Accumulation of Capital (London, 20I5); John Bellamy Foster, Brett Clark, Richard York, The Ecological Rift: Capitalism's War on the Earth (New York, 2010).

5. Jason W. Moore, “The End of Cheap Nature: Or How I Learned to Stop Worrying about 'The' Environment and Love the Crisis of Capitalism", in Christian Suter, Christopher Chase-Dunn (eds), Structures of the World Political Economy and the Future of Global Conflict and Cooperation (Berlin, 2014), pp. 28 5-314.

6. In recent years, the original "four cheaps" have been joined by other cheap things: Raj Patel, Jason W. Moore, A History of the World in Seven Cheap Things (London, 2018). 
the waste products generated by production and consumption. As new commodity frontiers opened, they created "peripheries" both in an economic and ecological sense: that is, they generated zones of exploitation that "exported" their fertility, water, energy, and genetic wealth to the metropoles, while simultaneously absorbing most of the ecological costs of production in the form of deforestation, erosion, and declining biodiversity (Figure I).

Put differently, the rise of the global capitalist economy was based on a process of unequal ecological exchange. ${ }^{7}$ And as global trade grew rapidly in the late nineteenth and twentieth centuries, this process of unequal exchange accelerated. The expansion of long-distance trade itself had a host of environmental consequences. Fundamentally, it helped liberate people's material expectations from the limits of local resources, at least for wealthy consumers in the industrial world. Moreover, while ever-lengthening commodity chains collapsed physical space, they also generated mental distance by separating consumers from areas of production and thereby obscuring the ecological consequences of overexploitation. So long as the flow of goods continued, few consumers or retailers in the industrial world had much concern for what was being damaged in the process. In all of these ways, the spatial detachment of production and consumption served to concentrate the benefits and the costs, ensuring that the net flow of resources (energy, minerals, nutrients, fertility) worked heavily in favour of the metropoles. The upshot was a "metabolic rift", a phenomenon that Marx himself wrote about in the midnineteenth century as a means of understanding the inequities of towncountryside exchanges. At the time, the problem he had in mind was the tendency of capitalist agriculture to break the age-old practices of nutrient cycling by failing to return wastes back to the soils that sustained the life of industrial cities. ${ }^{8}$ Over the following decades, however, such rifts became increasingly global in scale.

One scarcely needs to adopt an "eco-Marxist" perspective to recognize that unequal ecological exchange was part and parcel of the making of global peripheries. Although Bosma's book does not explicitly engage with such questions, they nonetheless lurk in the background. To its credit, The Making of a Periphery is sensitive to how ecological conditions influenced what was produced and how it was produced in different areas. Obviously, it was only

7. Alf Hornborg, "Ecosystems and World-Systems: Accumulation as an Ecological Process", in Christopher Chase-Dunn and Salvatore J. Babones (eds), Global Social Change: Historical and Comparative Perspectives (Baltimore, MD, 2006), pp. I6I-175; John Bellamy Foster, Hannah Holleman, "The Theory of Unequal Ecological Exchange: A Marx-Odum Dialectic”, Journal of Peasant Studies, 4I (2014), pp. 199-233.

8. John Bellamy Foster, "Marx's Theory of Metabolic Rift: Classical Foundations for Environmental Sociology", American Journal of Sociology, ros (1999), pp. 366-405; also Foster, Clark, York, The Ecological Rift; Jason W. Moore, "Environmental Crises and the Metabolic Rift in World-Historical Perspective”, Organization E Environment, I3 (2000), pp. I23-I 57. 


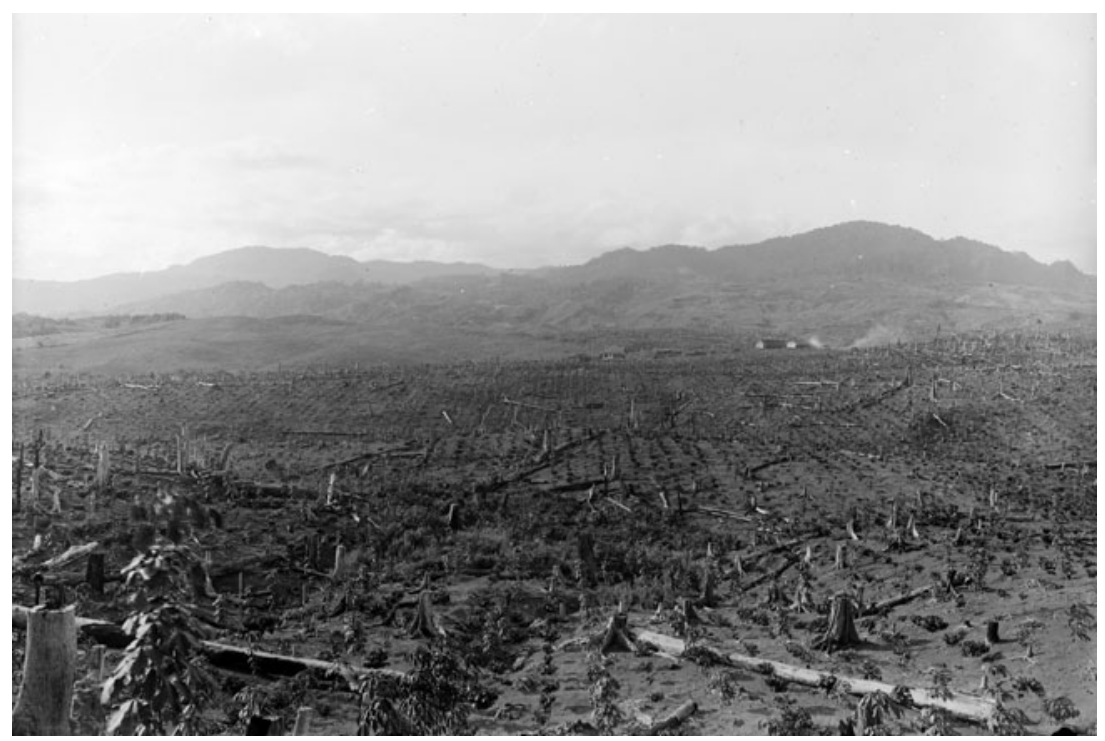

Figure I. Cleared forest on a new rubber planting at the Anggoli estate, East Sumatra, I919. Collection Tropenmuseum, Amsterdam, The Netherlands, inventory number: TM-I00I2838.

possible to grow certain crops in suitable climatic and soil conditions. When these conditions were particularly favourable, commercial producers benefited from what one might call an environmental rent. ${ }^{9}$ Even so, Bosma convincingly insists that modes of labour control were a more important determinant than ecological conditions for producing specific economic outcomes. As he rightly points out, landscapes are, after all, not just natural entities but are also the result of labour systems. ${ }^{10}$ It is a point that most environmental historians would readily agree with. As a whole generation of scholarship has shown, physical environments - even seemingly pristine "wildernesses" - are nearly always best understood as hybrid constructs of nature and culture. ${ }^{\text {II }}$

9. On "forest rent", see the seminal work by François Ruf, Booms et crises $d u$ cacao. Les vertiges de l'or brun (Paris, 1995), esp. pp. 91-1 59; it has also caught the attention of economists: Kurt Kratena, "From Ecological Footprint to Ecological Rent: An Economic Indicator for Resource Constraints", Ecological Economics, 64 (2008), pp. 507-516.

ı. Bosma, Making of a Periphery, p. 7; on the links between labour and nature more generally, see Thomas G. Andrews, "Work, Nature, and History: A Single Question, that Once Moved Like Light”, in Andrew C. Isenberg (ed.), The Oxford Handbook of Environmental History (Oxford, 20I4), pp. 425-466.

I I. See esp. William Cronon, "The Trouble with Wilderness; Or, Getting Back to the Wrong Nature”, Environmental History, I (1996), pp. 7-28; for subsequent debates about the pros and 
Yet, approaching landscapes as hybrid constructs means taking their biophysical make-up seriously. In particular, it requires us to investigate how their material constitution interacts with demographic, social, and political conditions to shape different outcomes. Simply put, it forces us to recognize that the "matter matters". ${ }^{22}$ This is true not only in the basic sense that ecological conditions set the outer limits within which human action could take place. Different environmental surroundings always open certain opportunities while impeding or discouraging others, and as people have pursued these opportunities to enhance their power, wealth, or well-being they further transformed their surroundings in a mutual process of co-evolution. The matter matters also in the sense that various production systems arranged human beings and other parts of nature in a multitude of different ways, and these arrangements could have highly divergent effects both for economies and for ecologies. This is not to suggest that particular crops, pests, or diseases exercised a full-blown form of historical "agency" comparable to that of humans (though debates about the so-called new materialism have raised fundamental questions about our understandings of causality and non-human agency). ${ }^{\mathrm{I}}{ }^{\mathrm{I}} \mathrm{It}$ is, however, to recognize that - following Bruno Latour - they constituted integral parts of a broader network of "actants", all of which mutually influenced each other and thereby shaped historical outcomes in the process. ${ }^{\mathrm{I}}$

The modern plantation can be regarded as one particular - and particularly important - version of such a network. Plantations were a central socioeconomic institution of the modern era and one of the world's most important modes of production. They came in a range of different shapes and sizes, grew an assortment of different crops, and adapted a variety of methods to diverse conditions. Most, however, shared a number of basic features; by and large their lowest common denominator was the employment of outside capital and low-wage labour for the intensive production of a specialized crop or limited set of crops for export. Plantations have long been a favourite topic for economic and social historians. For centuries, they defined commercial activity in the Atlantic world, and in many ways their simplification of complex activities into repetitive manual tasks presaged the modern factory system. More recently, they have also become a major focus of attention among

cons of writing about "hybrid nature", see the roundtable led by Paul Sutter in Journal of American History, 100: I (June 2013).

I 2. Frank Uekötter, "Matter Matters: Towards a More 'Substantial' Global History”, World History Bulletin, 29 (2013), pp. 6-8.

I 3. For useful discussions of these issues, see Hans Schouwenberg, "Back to the Future? History, Material Culture and New Materialism", International Journal for History, Culture and Modernity, 3 (2015), 59-72; T.J. LeCain, "Against the Anthropocene: A Neo-Materialist Perspective", International Journal for History, Culture and Modernity, 3 (2015), I-28.

I4. Bruno Latour, Reassembling the Social: An Introduction to Actor-Network-Theory (Oxford, $2005)$. 
environmental historians. As scholars have turned to concepts such as the "anthropocene" and "capitalocene" to help us make sense of the recent past, some have suggested the rather ungainly sounding "plantationocene" as a way of conceptualizing how our current era of ecological crisis is rooted in the project of environmental modernization, homogeneity, and control, which originally developed on plantations. ${ }^{\text {Is }}$

Plantations play an important role in The Making of a Periphery, and for good reason. They relied heavily on land-poor populations, and they eagerly grafted their activities on to existing client-patron relations in order to mobilize cheap labour. Where they were spatially concentrated, and how they operated, thus mirrored the demographic circumstances and mechanisms of labour control that Bosma singles out as key determining factors of the process of "peripheralization". Exactly how the evolution of plantations in Southeast Asia interacted with these factors is one of the more intriguing questions we can ask, especially in light of the distinction that Bosma draws between what he calls "peripheralization" and "incomplete peripheralization" ${ }^{16}$ : that is, between the so-called reversal of fortune in colonial heartlands such as Luzon and Java, which gradually transitioned from a position of relative wealth and power to a state of poverty and political weakness, and the "incomplete" relegation of outlying areas that were never as wealthy or powerful and that were not confronted by the same demographic pressures and labour relations, but that nonetheless came to occupy similarly subservient positions in the world economy via a somewhat different route. Without explicitly arguing the case, Bosma's account suggests a strong correlation between "peripheralization" in the heartlands and plantation modes of production (i.e. labourand capital-intensive methods deployed mainly by medium- to large-scale enterprises that specialized in a single crop or a small number of crops), and conversely between "incomplete peripheralization" and the predominance of smallholder production (i.e. land-extensive and mixed-cropping techniques, commonly employed by family groups but practiced at varying scales) on labour-scarce commodity frontiers. To the extent that the correlation holds, it serves as a useful entry point for integrating an environmental dimension into the book's core thesis. To paraphrase one of its central arguments, local demographic and social conditions led not only to the emergence of different patterns of labour and inequality, but also to a variety of different socioecological arrangements.

I s. On the global environmental history of plantations, see Frank Uekötter (ed.), Comparing Apples, Oranges, and Cotton: Environmental Histories of the Global Plantation (Frankfurt a. Main, 2014); on the "plantationocene", see Donna Haraway, "Anthropocene, Capitalocene, Plantationocene, Chthulucene: Making Kin”, Environmental Humanities, 6 (2015), pp. I59I65; also the discussion forum at https://edgeeffects.net/plantationocene-series-plantationworlds/; last accessed January 2020.

16. Bosma, Making of a Periphery, p. 103. 
Rubber production offers a vivid illustration. For one thing, it was a leading industry in Southeast Asia, the region of the world that dominated global production of natural latex for most of the twentieth century. Moreover, rubber was widely grown on both plantations and smallholdings. As with certain other crops, smallholders gradually came to dominate rubber production throughout most of the region. The conventional explanation for the supremacy of smallholders is that they were simply more efficient producers than large estates. Contemporaries and historians alike have long emphasized the competitive edge they enjoyed as a result of their lower cost base and smaller labour inputs per unit of output. Additionally, their mixed-cropping practices gave them a greater degree of flexibility to cope with the oscillations of volatile markets for raw materials. All of these economic factors are undoubtedly important. Less commonly recognized are the ecological dimensions of the smallholders' success: that is, the remarkable suitability of their production techniques and local forms of agronomic knowledge for successfully growing rubber trees in the various climatic and soil conditions of Southeast Asia. ${ }^{17}$

By nature, the Hevea brasiliensis tree (the preferred source of natural latex ever since the early twentieth century) is extremely well suited as a smallholder crop. Though native to the Amazon basin, it is easy to establish in tropical lowlands wherever there is well-drained soil, little temperature variation, and consistent but not excessive rainfall. Once established, it requires little maintenance. Tapping the latex-bearing sap is a fairly simple procedure involving modest equipment, yet cannot readily be mechanized. After tapping, the collected latex is relatively easy to coagulate and process into saleable form, again requiring little specialist equipment. All of this means that rubber provides growers with few economies of scale compared to many other tropical commercial crops (e.g. sugar, the other leading plantation crop in island Southeast Asia for much of the twentieth century). Overall, the particular requirements of the Hevea tree and the nature of the substance that it produced lent themselves to small-scale and land-extensive modes of production. Furthermore, the tendency towards smallholder rubber was reinforced by the fact that planters have to wait five to seven years before the trees are mature enough to yield an income, which gave a further advantage to those with low start-up costs and other sources of income in the meantime. ${ }^{18}$

17. On the environmental history of the rubber industry, see Corey Ross, Ecology and Power in the Age of Empire: Europe and the Transformation of the Tropical World (Oxford, 2017), pp. 99I35; Michitake Aso, Rubber and the Making of Vietnam: An Ecological History, I897-1975 (Chapel Hill, NC, 20I8); William Beinart, Lotte Hughes, Environment and Empire (Oxford, 2007), pp. 233-250. On the industry more generally: John Loadman, Tears of the Tree: The Story of Rubber. A Modern Marvel (Oxford, 2005); J.H. Drabble, Rubber in Malaya, I8761922: The Genesis of the Industry (Oxford, 1973); Colin Barlow, The Natural Rubber Industry: Its Development, Technology, and Economy in Malaysia (Oxford, 1978).

18. Generally: Ross, Ecology and Power, pp. 99-101; Drabble, Rubber in Malaya; Barlow, The Natural Rubber Industry. 
In the early twentieth century, rubber cultivation in Southeast Asia was initially centred on large plantations, which benefitted from generous state support in the allocation of land, various fee exemptions, and access to cheap (sometimes quasi-bonded) labour. But even where plantations enjoyed such political and economic advantages, the aforementioned characteristics of the Hevea tree meant that they were nonetheless naturally disadvantaged insofar as their capital and labour-intensive methods were not commensurately rewarded in higher productivity from the organisms they were cultivating. Moreover, some of the production methods that plantations deployed actually exacerbated these natural disadvantages.

European estate owners tended to pursue an "orchard" model characterized by mono-cropping, orderly rows, low tree density, clean weeding underneath, even ruler-straight ditches where drainage was needed (Figure 2). ${ }^{19}$ Such cultivation preferences, though expressed in the language of "rationality" and specialization, were rooted in culture as much as in economics. They reflected a powerful ideological attachment to "modern" agriculture as an embodiment of European knowledge and a symbol of European power over nature. Such methods contrasted sharply with the techniques employed by indigenous smallholders, whose denser patterns of rubber planting resulted in relatively spindly trees, and who expended little effort on maintenance activities such as weeding (hence their lower labour intensity). Despite the fact that the end product (smoked latex sheets) of such smallholdings differed little from what the estates produced, planters and colonial authorities perennially criticized their techniques as "primitive" and "irrational" compared to the allegedly more advanced and "scientific" methods deployed on plantations. Intriguingly, such criticisms persisted in spite of the remarkable efficiency exhibited by smallholder producers. In fact, the more the estates suffered from smallholder competition, the more some planters tended to disparage them. ${ }^{20}$

As it turned out, these denunciations of "primitive" smallholder methods were entirely misplaced, for in many respects the supposedly "rational" plantation techniques were - however aesthetically pleasing they might have been far less appropriate in the specific environmental conditions of lowland Southeast Asia. Clean weeding, for instance, was poorly suited to the light

19. It is worth noting that the deployment of such intensive methods proved impossible in Amazonia due to an endemic pest (a leaf blight fungus) that decimated concentrated Hevea stands there, but whose absence in Southeast Asia was a key factor behind the large-scale establishment of rubber plantations in the region. On the problems in Amazonia, see Barbara Weinstein, The Amazon Rubber Boom, I850-1920 (Stanford, CA, I983); Warren Dean, Brazil and the Struggle for Rubber: A Study in Environmental History (Cambridge, 1987).

20. Ross, Ecology and Power, pp. I20-I29; Michael R. Dove, "Rice-Eating Rubber and People-Eating Governments: Peasant versus State Critiques of Rubber Development in Colonial Borneo", Ethnohistory, 43 (1996), pp. 33-63. 


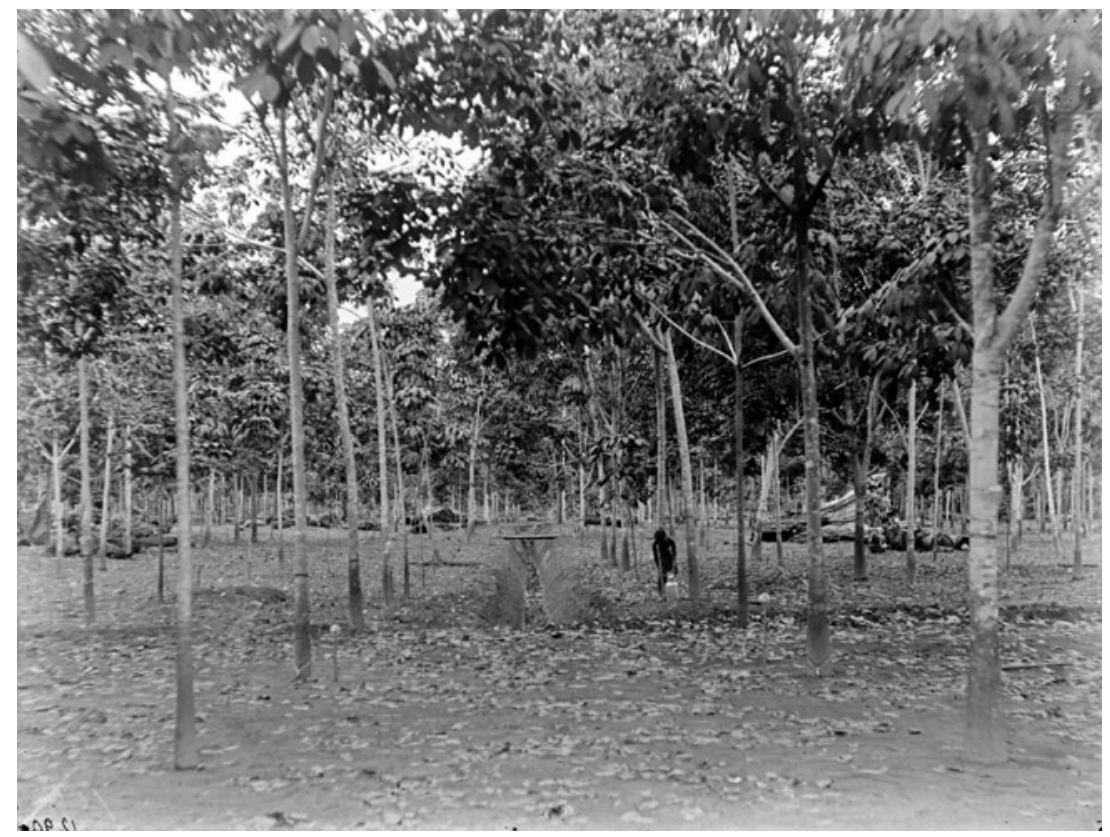

Figure 2. The 'orchard model' in action: Sangkoenoer Rubber Estate, East Sumatra, I919. Collection Tropenmuseum, Amsterdam, The Netherlands, inventory number: TM-I00I 2808.

soils and heavy rain regime throughout much of the region, and resulted in serious soil erosion and nutrient leaching (Figure 3). The estates' tendency to specialize on Hevea alone likewise posed significant risks, and not just from exposure to volatile markets. As some colonial agronomists had warned since the early years of the planting boom, uniform stands of a single species invited disease. Although none of the diseases that affected Southeast Asian growers were as serious as the leaf blight fungus that precluded plantation production of Hevea in its native Amazonia - a crucial factor behind the establishment of the Southeast Asian rubber industry in the first place - various forms of root fungus and canker became a significant problem on rubber estates after the igros. ${ }^{2 \mathrm{I}}$

Plantations, in other words, created highly unstable ecologies. Their particular arrangements of people, plants, soil, and water involved an extensive and ongoing alteration of the biophysical environment, and as such they could only be maintained with large inputs of labour and capital. In this sense, cheap labour made the new "nature" of the plantation, just as the nature of the plantation demanded large amounts of cheap labour. By comparison, 


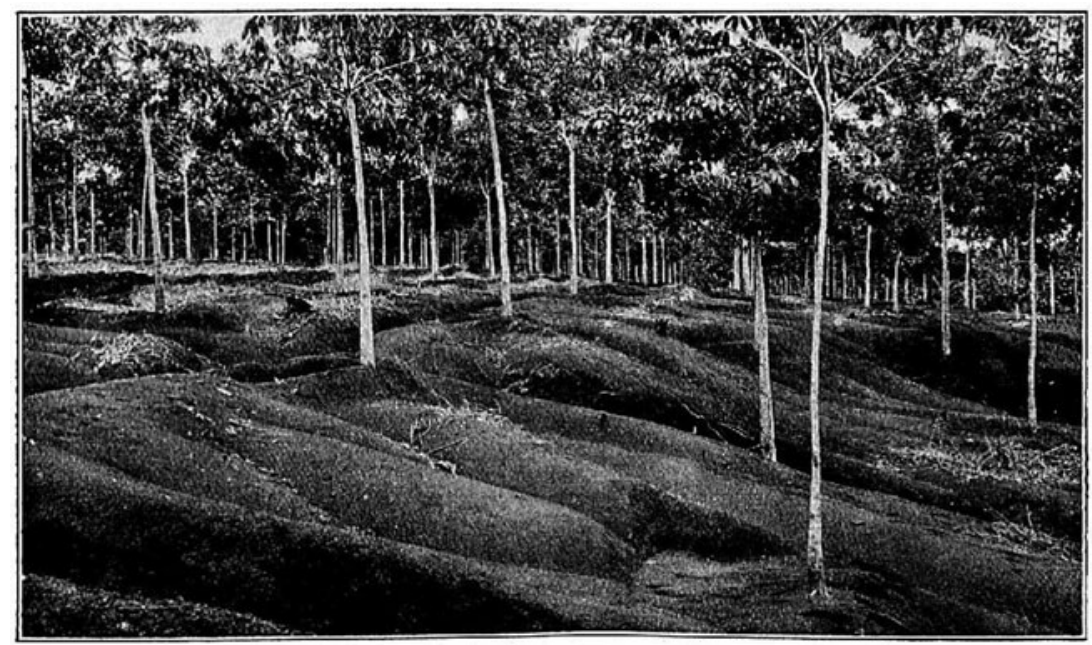

Figure 3. Erosive soil run-off on uneven terrain in a clean-weeded rubber stand. Swart, N.L., Rutgers, A.A.L. (eds), Handboek voor de Rubbercultuur in Nederlandsch-Indië (Amsterdam, I92 I), p. I39.

the supposedly "primitive" methods of indigenous growers had numerous benefits: they yielded well for much less work, they reduced disease because of the number of different species around, they aided humus formation, and they minimized erosion by retaining ground cover (Figure 4). In other words, smallholder rubber planters tended to create a more stable, lowerenergy arrangement. Although this arrangement did not require the same inputs to maintain, its output was roughly comparable because of the way in which soils, trees, and other species interacted. By the I930s, even colonial agronomists began to recognize the advantages of smallholder techniques and eventually urged estates to work more with nature rather than against it. Yet, change was slow and patchy; most planters continued to put their faith in modern science, which eventually gave them a reprieve in the form of higheryielding hybrid trees. Over the long-term, however, the "leakage" of such high-yield technologies beyond the estate sector once again demonstrated the competitiveness of smallholder rubber. ${ }^{22}$

In short, the familiar economic advantages of smallholder rubber cultivation were further boosted by a parallel set of ecological advantages. For our purposes here, the key point to recognize is that this complements and in some ways supports some of Bosma's main arguments. Above all, it indirectly reinforces his core thesis about the centrality of demography and labour relations

22. Ibid., pp. I 20-I 29; Barlow, Natural Rubber, pp. 76-77, I I 5-I 27, 444-445; Drabble, Economic History, pp. 220-22 I. 


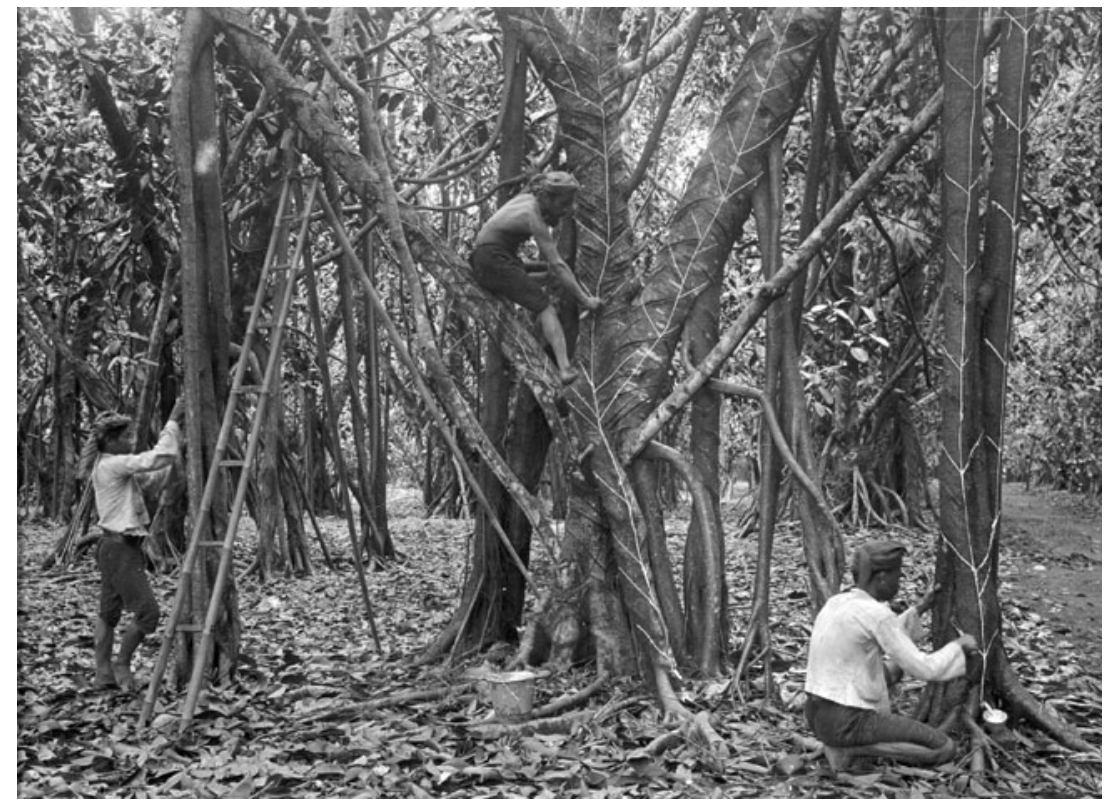

Figure 4. 'Native' rubber stand in the Netherlands East Indies.

Collection Tropenmuseum, Amsterdam, The Netherlands, inventory number: TM-60004I 82.

in the making of Southeast Asian peripheries. The different roles and outcomes of rubber plantations and smallholders offer additional evidence that the incorporation of island Southeast Asia into the global capitalist economy was far from the homogeneous process that others have portrayed, both for the environment and for the people who made a living from it. Estates and smallholdings differed not only in their cultivation techniques and organizational forms, but also in their biophysical and social effects.

Moreover, viewing these two modes of production as different socioecological arrangements actually strengthens Bosma's argument about the central importance of labour relations in the historical process of peripheralization. It has long been taken for granted that the profits of plantations rested largely on exploitative forms of labour control. Less obvious is the way in which environmental factors shaped the nature and degree of this exploitation. In the case of Southeast Asian rubber - like some other industries where estates faced intense smallholder competition (notably cocoa) ${ }^{23}$ - plantations

23. Gareth Austin, "Mode of Production or Mode of Cultivation: Explaining the Failure of European Cocoa Planters in Competition with African Farmers in Colonial Ghana", in William Gervase Clarence-Smith, Cocoa Pioneer Fronts since I 800: The Role of Smallholders, Planters and Merchants (Houndmills, 1996), pp. I 54-175; Ross, Ecology and Power, pp. 67-98. 
had to extract even more value from cheap labour in order to compensate for their socio-ecological disadvantages. Such environmental drawbacks had important social and political consequences, for they help to explain why the expansion of commodity frontiers into new production areas frequently entailed such regimented forms of work. For planters heavily invested in a particular place and a particular way of doing things, suppressing wages through the strict control of labour was often the only way of turning a profit from suboptimal adaptation to local ecological conditions.

The making of peripheries in the Global South was fundamentally a story of exploitation - of land, water, soils, and people. In Southeast Asia as elsewhere, it involved the reshaping of social and physical landscapes in tandem. The great strength of Bosma's book is its emphasis on the social complexities of this process without losing sight of the wider patterns of inequality that it helped to create. Adding an environmental dimension can augment the rich picture he paints by highlighting how social, ecological, and economic factors were entwined. Ultimately, wealth and power themselves - as well as their unequal distribution - are based on the ability to modify the rest of nature and harness its productivity for particular purposes. Just as social and environmental justice are closely linked in today's world, so too are social and environmental history for our understanding of the past. 